\title{
Clinical
}

\section{Metachronous tumors in a patient with Fanconi's anemia: case report}

\author{
Tumores metacrônicos em paciente portadora de Anemia de Fanconi: relato de caso
}

Luis Eduardo Silva Móz, MD, Phd ${ }^{1}$, Daniele Tramontina, MDㄹ, Mariana Cartaxo Alves, MD ${ }^{1}$, Natália Helena Valleta, MD ${ }^{1}$, Renan Sordi, MD Renata Tortato Meneguetti, MD¹, Cláudia Vaz de Melo Sette, MD², Daniel de Iracema Gomes Cubero, MD, Phd², Auro del Giglio, MD, Phd²

How to cite: Móz LES, Tramontina D, Alves MC, et al. Metachronous tumors in a patient with Fanconi's anemia: case report. Clin Onc Let. 2018;3(1-2):62-64. https://doi.org/10.4322/col.2018.008

\begin{abstract}
We present the case of a patient who entered early menopause at age 29 and was diagnosed with two primary tumors, bladder cancer at age 30 and esophageal cancer at 36 . She has family history of cancer, since her brother had esophageal cancer at age 29. Given her clinical status, we hypothesized Fanconi anemia, which was diagnosed by the diepoxybutane (DEB) test. The literature contains few case reports on the association between Fanconi anemia and esophageal cancer, and only one regarding its association with bladder cancer.
\end{abstract}

Keywords: Fanconi anemia, esophageal cancer, bladder cancer, case report.

\section{RESUMO}

Apresentamos um caso de uma paciente que teve menopausa precoce aos 29 anos e foi diagnosticada com dois tumores primários, sendo câncer de bexiga aos 30 anos e câncer de esôfago aos 36 anos. Ela também possui antecedente familiar oncológico, pois o seu irmão teve câncer de esôfago aos 29 anos. Frente ao quadro clínico, aventada a hipótese de Anemia de Fanconi, confirmada pelo DEB teste. Há poucos casos relatados na literatura de associação entre Anemia de Fanconi com câncer de esôfago, sendo encontrado apenas um relato da associação com câncer de bexiga.

Palavras-chave: Anemia de Fanconi, câncer de esôfago, câncer de bexiga, relato de caso

\section{INTRODUCTION}

Fanconi anemia (FA) is a rare autosomal recessive genetic disorder that mainly affects young adults. ${ }^{1}$ It is characterized by pancytopenia, congenital malformations and endocrinological disorders, and findings of early menopause and infertility are common. ${ }^{2}$ Predisposition for the occurrence of hematological and non-hematological malignancies, especially hepatic malignant neoplasia and squamous cell carcinoma (SCC) of the upper digestive tract, upper airway and anogenital region, has also been reported. ${ }^{3,4}$ DNA binding agents, such as diepoxybutane (DEB), have been used as diagnostic tests. ${ }^{5,6}$

\section{CASE REPORT}

The patient was a 37-year-old woman, ex-smoker (15 years smoking 1 pack/day), with a body mass index of $24.6 \mathrm{~kg} / \mathrm{m}^{2}$ and family history of esophageal neoplasia (brother, at age 29). At the age of 29, she entered menopause and at age 30 was diagnosed with low-grade bladder urothelial cancer, which was treated by local resection. Six years later, she developed a chronic dry cough and CT scans revealed pulmonary thromboembolism, the presence of a

\footnotetext{
${ }^{1}$ Departamento de Oncologia Clínica, Instituto Brasileiro de Controle do Câncer, São Paulo, Brazil

${ }^{2}$ Centro de estudos e pesquisa de Hematologia e Oncologia, Faculdade de Medicina do ABC, Santo André, Brazil

Financiamento: Não houve financiamento para o presente estudo.

Conflito de interesse: Os autores declararam não haver conflitos de interesse que precisam ser informados.
} 
pulmonary nodule measuring $1.1 \mathrm{~cm}$ in the middle lobe, left and cervical supraclavicular (smallest diameter $1.5 \mathrm{~cm}$ ) and mediastinal lymph node enlargement (smallest diameter $2.2 \mathrm{~cm}$ ). Anatomopathological investigation of the cervical lymphadenomegaly revealed a hidden primary lesion of SCC. Given the symptomatology, the first line of chemotherapy - cisplatin plus gemcitabine - was initiated as a matter of urgency, combined with intense hemoptysis after the first application. The patient was submitted to bronchoscopy and digestive endoscopy, which revealed the presence of an ulcerated lesion in the middle third of the esophagus. A biopsy confirmed invasive esophageal SCC. Mediastinal radiotherapy (dose: $3000 \mathrm{~Gy}$ ) was prescribed based on the marked reduction in tracheal lumen caused by tumoral infiltration of the mucosa. Positron emission computed tomography (PET-CT) revealed disease progression, thickening in the middle third of the esophagus (SUV 7.6); cervical ( $1 \mathrm{~cm}$; SUV 13.3) and paratracheal lymph node enlargement $(0.8 \mathrm{~cm}$; SUV 8.5), nodular pericardial formations (up to $1.9 \mathrm{~cm}$; SUV 19.3), multiple pulmonary nodules (SUV 8.9), hepatic nodules $(1.1 \mathrm{~cm}$; SUV 9.1) and lymph node enlargement in the hepatogastric recess (SUV 7.6). A second line of chemotherapy was initiated, carboplatin plus paclitaxel weekly, but the patient presented myelotoxicity after two cycles and required hospitalization for febrile neutropenia. PET-CT showed evidence of esophageal, lymph node, pulmonary and hepatic disease progression, associated with pleural and pericardial effusion, with evolution to cardiac tamponade and the need for drainage. Faced with the disease severity and the drop in treatment performance, the medical team opted for exclusive palliative care. A diagnosis of FA was suspected because of her clinical history of cancer, prior early menopause and family history. On the day of her death, a DEB test was performed that was positive for FA.

\section{DISCUSSION}

Reports in the literature regarding the association between Fanconi anemia and esophageal cancer are scarce. The highest incidence occurs in young women not submitted to bone marrow transplantation. ${ }^{7}$ Kutler et al. ${ }^{8}$ Rosenberg et al., ${ }^{4}$ and Rosenberg et al., ${ }^{9}$ described a profile of cancer incidence in patients with FA. Relating the cases of esophageal cancer to the number of solid malignancies, they found a ratio of $1 / 79,2 / 18,2 / 12$, respectively.

In a review of the literature, Shimamura and Alter $^{10}$ found 124 patients who presented associations between FA and a solid malignant neoplasm. Of these, 14 patients had esophageal cancer and only one male patient had bladder cancer. Thus, the patient discussed here is the second to be diagnosed with FA and bladder cancer and the first woman reported with this association.

While following eight patients with FA, Itskoviz et al. ${ }^{11}$ diagnosed esophageal cancer in two patients, 8 and 18 months after the onset of endoscopic follow-up. Due to the increased risk of developing neoplasms of the upper digestive tract, early and periodic endoscopic follow-up is an important feature of patient care.

\section{CONCLUSION}

In the general population, the occurrence of FA is rare and this can cause late diagnoses, inadequate follow-up and a decrease in patient survival. This case shows that in young patients with endocrinological disorders, a diagnosis of malignant neoplasia and with family history of cancer, genetic syndromes like FA should be included in the differential diagnosis. Moreover, early diagnostic tests for correct genetic counseling and regular follow-up of patients and relatives are recommended.

\section{REFERENCES}

1. Sachiyo O, Masahiro T, Tsutomu T, et al. A case of superficial esophageal cancer in a Fanconi Anemia patient that was treated successfully by endoscopic submucosal resection. Intern Med. 2019;58(4):1434.18. https://doi.org/10.2169/internalmedicine.1434-18.

2. Petryk A, Shankar RK, Giri N, et al. Endocrine disorders in Fanconi Anemia: recommendations for screening and treatment. J Clin Endocrinol Metab. 2015;100(3):803-11. http://dx.doi.org/10.1210/jc.2014-4357. PMid:25575015.

3. Offit K, Levran O, Mullaney B, et al. Shared genetic susceptibility to breast cancer, brain tumors, and Fanconi anemia. J Natl Cancer Inst. 2003;95(20):1548-51. http://dx.doi.org/10.1093/jnci/djg072. PMid:14559878. 
4. Rosenberg PS, Greene MH, Alter BP. Cancer incidence in persons with Fanconi anemia. Blood. 2003;101(3):822-6. http://dx.doi.org/10.1182/blood-2002-05-1498. PMid:12393424.

5. Auerbach AD. Fanconi anemia and its diagnosis. Mutat Res. 2009;668(1-2):4-10. http://dx.doi.org/10.1016/j.mrfmmm.2009.01.013. PMid:19622403.

6. Auerbach AD. Diagnosis of Fanconi Anemia by Diepoxybutane analysis. Curr Protoc Hum Genet. 2015;85:1-17. PMid:25827349.

7. Hosoya Y, Lefor A, Hirashima Y, et al. Successful treatment of esophageal squamous cell carcinoma in a patient with Fanconi anemia. Jpn J Clin Oncol. 2010;40(8):805-10. http://dx.doi.org/10.1093/jjco/hyq049. PMid:20410055.

8. Kutler DI, Singh B, Satagopan J, et al. A 20-year perspective on the International Fanconi Anemia Registry (IFAR). Blood. 2003;101(4):1249-56. http://dx.doi.org/10.1182/blood-2002-07-2170. PMid:12393516.

9. Rosenberg PS, Alter BP, Ebell W. Cancer risks in Fanconi anemia: findings from the German Fanconi Anemia Registry. Haematologica. 2008;93(4):511-7. http://dx.doi.org/10.3324/haematol.12234. PMid:18322251.

10. Shimamura A, Alter BP. Pathophysiology and management of inherited bone morrow failure syndromes. Blood Rev. 2010;24(3):101-22. http://dx.doi.org/10.1016/j.blre.2010.03.002. PMid:20417588.

11. Itskoviz D, Tamary H, Krasnov T, et al. Endoscopic findings and esophageal cancer incidence among Fanconi Anemia patients participating in an endoscopic surveillance program. Dig Liver Dis. 2019;51(2):242-6. PMid:30249500. 